Krzysztof Śleziński

Uniwersytet Śląski, Katowice

ORCID: 0000-0002-6662-3871

e-mail: krzysztof.slezinski@us.edu.pl

\title{
Filozoficzne implikacje zmieniającego się obrazu rzeczywistości przyrodniczej
}

DOI: http://dx.doi.org/10.12775/RF.2019.054

Teorie nauk szczegółowych kształtują określone wyobrażenia rzeczywistości przyrodniczej. Wyobrażenia te ulegają zmianom pod wpływem rozbudowywania oraz tworzenia nowych teorii. W literaturze naukowej na określenie tego zagadnienia stosowany jest często termin „obraz rzeczywistości przyrodniczej", który nie ma jednoznacznego znaczenia, spełnia jednak ważną heurystyczną rolę w filozofii przyrody. W niniejszym opracowaniu przez "obraz rzeczywistości” będę rozumiał takie przedstawienie procesów przyrodniczych, jakie są dopuszczane przez teorie naukowe. Obraz rzeczywistości jest dla mnie czymś odmiennym od treści aktów zmysłowego postrzegania rzeczywistości przyrodniczej. Ujednolicenie tak rozumianego obrazu rzeczywistości z treściami tych aktów miało miejsce przed sformułowaniem szczególnej i ogólnej teorii względności oraz mechaniki kwantowej. $W$ okresie tym powszechnie posługiwano się zdroworozsądkowym opisem rzeczywistości, zgodnym $\mathrm{z}$ teoretycznym, deterministycznym i mechanicystycznym jej obrazem. Obecnie, odwołując się do obowiązujących teorii naukowych, wyobrażenie rzeczywistości przyrodniczej daleko odbiega od zdroworozsądkowego pojmowania otaczającej nas rzeczywistości. Zadaniem filozofii przyrody i przyrodoznawstwa jest poszukiwanie i dobór takich kategorii pojęciowych, które dałyby spójną interpretację zjawisk przyrodniczych, a tym samym umożliwiły zbudowanie takiego obrazu rzeczywistości przyrodniczej, który pozostawałby w zgodzie z treściami naukowych teorii. 
W niniejszym artykule pragnę jedynie zasygnalizować, w odniesieniu do wybranych obszarów badań matematycznych i przyrodniczych, potrzebę ciągłego opracowywania zmieniającego się obrazu rzeczywistości przyrodniczej. Odwołując się do badań dotyczących matematycznego prawdopodobieństwa, problematyki przypadku oraz badań procesów dyssypatywnych i obowiązywania drugiej zasady termodynamiki, można wyróżnić m.in. takie pojęcia, jak: „emergencja”, „bifurkacja”, „,superweniencja”, "dyssypacja”, które mogą wchodzić w zakres ogólnego wyjaśniania procesów przyrodniczych badanych przez współczesne teorie naukowe. Pojęcia te można traktować jako konstytuujące aktualny obraz rzeczywistości przyrodniczej.

Zachodząca w czasie ewolucja idei i systemów pojęciowych w teoriach naukowych zmienia nasze wyobrażenia rzeczywistości przyrodniczej. Przechodzę zatem do kilku wyróżnionych obszarów badań w celu ukazania możliwości wzięcia ich pod uwagę do takiego opracowania obrazu rzeczywistości, który odpowiadałby obecnemu poziomowi posiadanej wiedzy naukowej.

\section{Konstytuowanie się nowego obrazu rzeczywistości przyrodniczej}

Problematyka prawdopodobieństwa, a wraz z nią problem przypad$\mathrm{ku}$ stanowily $\mathrm{w}$ ostatnim okresie przedmiot nowatorskich opracowań w wielu obszarach - od matematycznej teorii prawdopodobieństwa po teorię chaosu deterministycznego. Wyniki tych prac doprowadziły do radykalnej zmiany rozumienia zjawisk przyrodniczych. To, co wcześniej uważano za przejaw niewytłumaczalnej przypadkowości, niezaplanowanej koincydencji zdarzeń, okazało się przejawem wyrafinowanego porządku odsłaniającego złożoność badanych zjawisk. Rezultaty badań przyrodniczych, ukazując uproszczenia w tradycyjnym rozumieniu przypadku, wymagają nowej perspektywy jego ujęcia i opracowania właściwej jego filozofii, która byłaby zadowalającym wyjaśnieniem przebiegu ewolucji kosmicznej i ewolucji biologicznej. O ile koncepcja ewolucji kosmicznej nie wiedzie do jej fundamentalnej krytyki, mimo iż doprowadziła do rewizji powszechnie przyjmowanych wyobrażeń o miejscu człowieka w procesie kosmicznych przemian, o tyle ewolucja biologiczna nadal wzbudza emocje i liczne spory przebiegające na płaszczyźnie światopoglądowej, przyrodniczej, filozoficznej oraz teologicznej.

Moim zadaniem nie jest szczegółowe omówienie etapów prac dotyczących filozofii przypadku. Na ten temat istnieje już bardzo obszerna literatura. Kilka poniższych uwag ma jedynie zasygnalizować i nakreślić złożoność oraz wieloaspektowość tych badań. 
W ostatnich dwóch wiekach szybki rozwój problematyki prawdopodobieństwa wypływał przynajmniej z trzech źródeł. Jednym z nich było stosowanie rachunku matematycznego do gier hazardowych. Z chwilą kiedy de Méré zwrócił się do Pascala z prośbą o ekspertyzę, jak obstawiać w grach losowych, chęć zysku stała się potężną siłą napędową rozwoju rachunku prawdopodobieństwa. Na tej drodze rachunek ten odnalazł matematyczną, właściwą ścieżkę rozwoju. Kolejnym źródłem problematyki prawdopodobieństwa były próby uzasadnienia poznawczej prawomocności rozumowań indukcyjnych, stosowanych w naukach empirycznych. Podejmowano liczne próby budowy logiki indukcji, najczęściej odwołujące się do interpretacji subiektywistycznej lub logicznej prawdopodobieństwa ${ }^{1}$.

Trzecim źródłem problematyki prawdopodobieństwa były rozwijające się w XIX wieku teorie fizyczne. Badania w zakresie teorii ciepła, kinetycznej teorii gazu, teorii błędu pomiaru, statystycznej interpretacji drugiej zasady termodynamiki doprowadziły do ukonstytuowania się mechaniki statystycznej, która Ludwigowi Bolzmannowi posłużyła do wyjaśnienia ruchów Browna oraz statystycznego opisania praw termodynamiki. Przełomem w badaniach przyrodniczych było jednak stworzenie teorii kwantowej. W początkowej fazie rozwoju tej teorii trudności interpretacyjne dotyczące obserwowanych stanów kwantowych prowadziły do traktowania ich w kategoriach indeterminizmu ${ }^{2}$. Do wyjaśniania tych stanów próbowano wykorzystać także teorię prawdopodobieństwa opracowaną przez Andrieja Kołmogorowa, którą zaczęto traktować jako szczególny przypadek teorii miary³.

W naukach przyrodniczych dokonał się zwrot w badaniach przypadku i prawdopodobieństwa. Badania układów dalekich od równowagi termodynamicznej okazały się przełomowe w rozumieniu procesów złożonych. W odróżnieniu od termodynamiki liniowej, równowagowej, dotyczącej procesów odwracalnych termodynamika nierównowagowa badaniem objęła układy poza stanem równowagi oraz procesy nie-

1 Adam Grobler, Metodologia nauk (Kraków: Wydawnictwo Aureus - Wydawnictwo Znak, 2006), 23-61; Hans Reichenbach, The Theory of Probability: An Inquiry into the Logical and Mathematical Foundations of the Calculus of Probability, przeł. Ernest H. Hutten, Maria Reichenbach (Berkeley, Los Angeles: University of California Press, 1949); Krzysztof Śleziński, „Prawdopodobieństwo w argumentacji filozoficznej”, Bielsko-Żywieckie Studia Teologiczne 13 (2012): 249-260.

2 Krzysztof Śleziński, „Determinizm i indeterminizm w dyskusji metanaukowej połowy XX wieku", Bielsko-Żywieckie Studia Teologiczne 4 (2003): 301-310.

${ }^{3}$ Przeglądową zmianę pojęć związanych z prawdopodobieństwem i przypadkiem zawierają dwie pierwsze części pracy M. Hellera: Michał Heller, Filozofia przypadku. Kosmiczna fuga z preludium i coda (Kraków: Copernicus Center Press, 2012), 19-213; Ilya Prigogine, Isabelle Stengers, Z chaosu ku porzadkowi. Nowy dialog człowieka z przyroda, przeł. Katarzyna Lipszyc (Warszawa: Państwowy Instytut Wydawniczy, 1990), 143-191. 
odwracalne. Pierwsze związki w termodynamice nierównowagowej, obowiązujące w obszarze liniowym, odkrył Lars Onsager. Okazało się, że obszary tego typu ewoluują ku stanom ustalonym, nierównowagowym, w których zachodzą procesy dyssypatywne, czyli rozproszeniowe. Oznacza to, że w stanie ustalonym aktywność układu bezustannie zwiększa entropię swego otoczenia, a sam układ zmierzający do tego stanu przekazuje otoczeniu tak małą entropię, jak tylko na to pozwalają nałożone na układ warunki brzegowe ${ }^{4}$. Z kolei Ilya Prigogine sformułował ogólne zasady rządzące układami nierównowagowymi i przedstawił makroskopowy opis procesów zbliżania się do stanu równowagi. W pewnych wypadkach, w układach nierównowagowych, fluktuacje potęgują się i obejmują całość tego układu, zmuszając go do ewoluowania $w$ kierunku nowych stanów atraktorowych, niekiedy zupełnie jakościowo różnych od stanów ustalonych, odpowiadających minimum produkcji entropii.

Wszystkie procesy twórcze $\mathrm{w}$ przyrodzie zachodzą w stanach dalekich od równowagi. Każdy układ będący w równowadze termodynamicznej, likwidując różnice energetyczne, „zastyga w rozwoju”, dlatego też termodynamika liniowa, która zajmowała się co najwyżej stanami niedalekimi od równowagi, nie potrafiła wyjaśnić powstawania nowych, coraz bardziej złożonych struktur. Sprostała temu dopiero termodynamika nieliniowa wykorzystująca matematyczną teorię układów dynamicznych ${ }^{5}$. Okazało się, że w stanach odległych od równowagi mogą istnieć trwałe, ale niestatyczne struktury, które pod wpływem wewnętrznych i zewnętrznych fluktuacji są narażone na przemianę. Fluktuacje te wprowadzają do układu element indeterminizmu i wówczas układ może podążać jedną z wielu możliwych dróg. Po wyborze danej drogi, czyli przejściu fazowym, bifurkacji, układ przejawia nowe jakości, a sam stabilizuje się.

Rezultaty badań układów dynamicznych wykorzystuje się w wyjaśnianiu przykładowo genezy życia czy ewolucji Wszechświata. W zakresie filozofii przyrody ożywionej tego typu próby zaproponowali m.in. Szczepan W. Ślaga czy Wiesław Dyk, który w pracy Termodynamiczne aspekty genezy życia dokonał oszacowania wkładu termodynamiki

${ }^{4}$ Michał Heller, Józef Życiński, Dylematy ewolucji (Tarnów: Wydawnictwo Biblos, 1996), 125-129.

${ }^{5} \mathrm{O}$ teorii układów dynamicznych zob. np.: Wiesław Szlenk, Wstęp do teorii gładkich układów dynamicznych (Warszawa: Państwowe Wydawnictwo Naukowe, 1982); Aleksander Aleksandrovich Andronov, Eugenie Leontovich-Andronowa, I. I. Gordon, A. G. Maier, Theory of Bifurcations of Dynamic Systems on a Plane (Jerusalem: Israel Program for Scientific Translations, 1971); Wladimir Igorevich Arnold, Równania różniczkowe zwyczajne (Warszawa: Państwowe Wydawnictwo Naukowe, 1975). 
w wyjaśnianiu abiogenezy ${ }^{6}$. Dyk powołał się na zjawisko ewolucji układów biologicznych, wykorzystując m.in. wyniki badań stanów dalekich oraz bliskich równowagi, w których zauważa się zjawisko fluktuacji o różnym stopniu nasilania się. Początkowo w układzie fluktuacje pojawiają się w ograniczonym obszarze, a gdy jego wielkość przekroczy określoną wartość krytyczna, wówczas fluktuacje rozprzestrzeniają się na cały układ. Fluktuacje występujące poniżej określonej wartości krytycznej ulegają stłumieniu i wówczas ewolucja układu jest procesem deterministycznym, podległym prawom makroskopowym ${ }^{7}$. W układach biofizycznych, wskutek przekroczenia średnich wartości temperatury, ciśnienia i innych wartości progowych oraz tworzenia się nowych struktur, załamuje się opis makroskopowy. Fluktuacje układu przyjmującego wartości krytyczne zmieniają ewolucję układu z deterministycznego na stochastyczny. Taki układ, rozwijając się, przechodzi cyklicznie do nowych niestabilnych stanów. Układ, podążając szeregiem możliwych dróg, dokonuje „wyboru” jednej z nich i proces toczy się dalej, ale już $w$ innym reżimie, rodząc nową jakość.

Z kolei zwracając uwagę na właściwości fluktuacji materii we Wszechświecie, zauważamy, że są one skutkiem pewnych historycznych zbiegów okoliczności. Fakt powstania gwiazdy lub planety w danym miejscu zależy od złożonego łańcucha wydarzeń, które teoretycznie da się prześledzić aż do pewnej początkowej cechy Wszechświata ${ }^{8}$. Właściwości Wszechświata, ale także właściwości cząstek elementarnych, mogą zależeć od ewolucji, która może być wynikiem jego warunków początkowych, na co zwracają uwagę: Maurizio Gasperini, Brian Greene $^{9}$, Stephen Hawking, Andriej Linde ${ }^{10}$, Roger Penrose, Lee Smolin ${ }^{11}$ czy Gabriel Veneziano. Są też i takie prace, w których przyjmuje się możliwość istnienia stanów naszego Wszechświata przed tzw. wielkim wybuchem. W pracach tego typu stawia się pytanie: dlaczego Wszechświat się

${ }^{6}$ Wiesław Dyk, „Termodynamiczne aspekty genezy życia”, Z Zagadnień Przyrodoznawstwa i Filozofii Przyrody 11 (1996): 156-163.

7 Dmitrij S. Czernawski, Jurij M. Romanowski, Natalia W. Stiepanowa, Modelowanie matematyczne w biofizyce, przeł. Ewa Skrzypek (Warszawa: PWN, 1979), 294.

8 Zob. np.: Steven Weinberg, Sen o teorii ostatecznej, przeł. Piotr Amsterdamski (Warszawa: Wydawnictwo Alkazar, 1994); John D. Barrow, Teorie wszystkiego. W poszukiwaniu ostatecznego woyjaśnienia, przeł. Jan Czerniawski, Tomasz Placek (Kraków: Znak, 1995); Paul Davies, Plan Stwórcy. Naukowe podstawy racjonalnej wizji świata, przeł. Marek Krośniak (Kraków: Znak, 1996).

9 Brian Greene, Piękno Wszechświata. Superstruny, ukryte wymiary i poszukiwanie teorii ostatecznej, przeł. Ewa L. Łokas, Bogumił Bieniok (Warszawa: Prószyński i S-ka, 2002).

${ }_{10}$ Andrei Dmitriyevich Linde, „Eternally Existing Self-Reproducing Chaotic Inflationary Universe", Physics Letters B, 175 (1986) 4: 395-400.

${ }^{11}$ Lee Smolin, Time Reborn. From the Crisis in Physics to the Future of the Universe (Boston, New York: Hunghton Mifflin Harcourt, 2013), 123-211. 
zaczął? Z taką próbą mamy do czynienia przykładowo w opracowanej przez Penrose'a konforemnej kosmologii cyklicznej ${ }^{12}$. Jego propozycja jest alternatywą dla koncepcji kosmicznej inflacji i opowiedzeniem się za nieprzypadkowością warunków początkowych Wszechświata przy jednoczesnym obowiązywaniu drugiej zasady termodynamiki.

Obecnie nie można bezwzględnie twierdzić, że Wszechświat powstał przypadkowo. Bardziej prawomocne, w perspektywie badań kosmologicznych, jest stwierdzenie o emergencyjnym jego pochodzeniu ${ }^{13}$. Problemem pozostaje jednak to, jak doszło do jego powstania. Problematyka istnienia Wszechświata, jego początku i jego matematycznego modelowania implikuje bogactwo treści filozoficznych. Pojawiają się matematycznie usprawiedliwione nowe rozumienia czasu, związków przyczynowych, czasoprzestrzennej struktury i rodzajów istnienia obiektów naszego Wszechświata. Przed filozofią przyrody stawiane są nowe wyzwania, które musi ona podjacć, jeśli ma być wsparciem dla nauk przyrodniczych i pomocą w próbach rozumienia rzeczywistości ${ }^{14}$.

\section{W kręgu idei strukturalnej nowości}

Złożoność przejawia się na wielu poziomach rzeczywistości przyrodniczej, tworząc struktury wewnątrz struktur. Okazuje się, że poszczególne poziomy organizacji nie są od siebie niezależne ani w pełni autonomiczne. Tworzące się systemy wyższego rzędu są przynajmniej częściowo determinowane przez ich wewnętrzne struktury. Dotyczy to nie tylko atomów, związków chemicznych, ale także komórek i organizmów wielokomórkowych. Zjawisko to obserwujemy przede wszystkim w pro-

12 Roger Penrose, Cykle czasu. Nowy niezwykty obraz Wszechświata, przeł. Bogumił Bieniok, Ewa L. Łokas (Warszawa: Prószyński i S-ka, 2011), 156-166.

${ }_{13}$ Przez emergencję należy $\mathrm{w}$ tym miejscu rozumieć wyłanianie się nowości, nowych cech układu z określonych determinantów zachodzących na niższym poziomie. Przy czym zaistnienie tych determinantów na niższym poziomie stanowi jedynie warunek konieczny, ale niewystarczający, występowania danych procesów lub nowych jakości na wyższym poziomie.

${ }^{14}$ Dyskutowana kwestia nie jest zarezerwowana jedynie dla badań z zakresu filozofii przyrody. Inne dziedziny badań filozoficznych także ją podejmują; przykładem tego może być próba Michała Hellera dotycząca opisu rozwoju teorii naukowych, wykorzystująca ideę rozwoju struktur dyssypatywnych. Zwracając uwagę na procesy twórcze w przyrodzie, dziejące się w stanach dalekich od równowagi termodynamicznej, zaproponował interesujący nieliniowy model rozwoju nauki. W modelu tym konkurujące teorie naukowe, przechodząc przez poszczególne punkty bifurkacji, ukazują dynamizm badań naukowych. Michał Heller, Fizyka ruchu i czasoprzestrzeni (Warszawa: PWN, 1993), 175-180. 
cesach fizycznych, chemicznych i biologicznych ${ }^{15}$. Dyskusje dotyczące relacji „międzypoziomowych" często są sprowadzane do zagadnień redukcji, emergencji, superweniencji ${ }^{16}$. Każde $\mathrm{z}$ tych zagadnień uzyskało wiele rozmaitych interpretacji. W ostatnich kilku dekadach problematykę relacji międzypoziomowej najczęściej omawia się przy użyciu takich pojęć, jak: „system”, „superweniencja” czy „emergencja”"17. Analizy kategorii superweniencji i emergencji służą obecnie wypracowaniu wzorców interpretacyjnych otaczającej nas rzeczywistości, które przezwyciężają schematy myślenia mechanicystycznego i równocześnie ukazują bezpodstawność najprostszych wersji naturalizmu.

Analizując relacje międzypoziomowe, zauważamy, że wielu filozofów i naukowców odeszło od interpretowania świata w kategoriach monizmu ontologicznego. Pluralizm ontologiczny jest przyjmowany m.in. przez: Karla R. Poppera, George'a F. R. Ellisa, Rogera Penrose'a czy Józefa Życińskiego.

Aprobowaną przez Poppera koncepcję emergencji należy ujmować $\mathrm{w}$ ścisłym związku z akceptowanym przez niego fundamentalnym indeterminizmem świata fizycznego, w którym wyróżnia trzy jego pozio$m y^{18}$. Każdy z tych poziomów jest otwarty na przyczynowe wpływanie na siebie innych poziomów. Popper, mając to na uwadze, wypracował koncepcję trzech światów: świat 1. (obiektów fizycznych), świat 2. (doświadczeń subiektywnych) i świat 3. (wytworów umysłu ludzkiego) ${ }^{19}$.

Zdaniem Poppera etapy ewolucji wszechświata, a przynajmniej niektóre z nich, wytwarzają w sposób całkowicie nieprzewidywalny rzeczy wraz z ich własnościami. W ten sposób w świecie 1. produkowane cięższe pierwiastki chemiczne prowadzą do powstania cieczy i kryształów. W świecie 2. emergencja życia, przejawiającą się w przekazywaniu informacji, doprowadza człowieka do zdobycia świadomości siebie i świadomości zmierzania ku śmierci. Z kolei w świecie 3. emergencja ludzkiego języka umożliwia wyjaśnianie naszego istnienia oraz wyłanianie

15 Peter Coveney, Roger Highfield, Granice złożoności. Poszukiwania porzadku w chaotycznym świecie, przeł. Piotr Amsterdamski (Warszawa: Prószyński i S-ka, 1997), 198-227.

${ }_{16}$ Przez superweniencję będziemy rozumieć takie pojawienie się nowej własności układu, kiedy własność ta superweniuje na danym podłożu (nazwijmy go „danym poziomem strukturalnym"), a wówczas wystąpienie tego podłoża pociąga za sobą w stopniu koniecznym wystąpienie tej własności. Superweniencja stanowi warunek konieczny, lecz niewystarczający, emergencji.

${ }_{17}$ Na niejednoznaczność rozumienia takich pojęćjak „,emergencja” zwraca uwage Robert Poczobut w artykule "System - struktura - emergencja”, w: Struktura i emergencja, red. Michał Heller, Janusz Mączka (Tarnów: Polska Akademia Umiejętności, Wydawnictwo Biblos, 2006), 11-38.

18 Karl Raimund Popper, John Carew Eccles, The Self and Its Brain (New York: Springer International, 1977), 35.

19 Popper, Eccles, The Self and Its Brain, 17. 
się takich produktów ludzkiego umysłu, jak: formułowanie wyjaśnień mitycznych, tworzenie teorii naukowych czy dzieł sztuki.

Popper, w próbach wyjaśnienia pojawiających się nowości w zjawiskach fizycznych, odwołuje się także do skłonnościowej interpretacji prawdopodobieństwa ${ }^{20}$. Według tej interpretacji klasyczna teoria prawdopodobieństwa jest niemożliwa do utrzymania, ponieważ odwołuje się do zdarzeń, które mają tę samą miarę możliwości swego zaistnienia ${ }^{21}$. Teorię tę należy zastąpić ogólną teorią prawdopodobieństwa, która traktując o wszelkiego rodzaju przypadkach nierównych możliwości, wyjaśnia istnienie określonych tendencji lub skłonności układów do zajścia pewnych zdarzeń. Skłonności układów prowadzące do zaistnienia danego zdarzenia są możliwe do oszacowania dzięki metodzie statystycznej ${ }^{22}$.

Popper przypisuje skłonnościom realne istnienie, podobne do tego, jakie w fizyce nadaje się siłom i obiektom fizycznym. W tym miejscu możemy mówić o tzw. polu skłonności, które oddziałuje na każde pojedyncze zdarzenie. Zdaniem Poppera nie istnieje żaden powód nieuwzględniania interakcji między skłonnościami, a tym samym powstawania skłonności w danym miejscu, zależnie od skłonności zachodzących w otoczeniu danego układu ${ }^{23}$. Zawsze istnieje wiele skłonności o wartościach większych od zera, które nigdy nie zrealizują się. Może to mieć miejsce $\mathrm{w}$ sytuacji, kiedy pojawiająca się szansa na realizację danej skłonności jest powstrzymywana przez zmianę stanu danego układu.

Zdaniem Poppera przyszłość świata i życia zawsze pozostaje otwarta. W ewolucji życia istniały i istnieją nieskończone możliwości. Zrealizowały się jednak tylko te nieliczne, które mogły się urzeczywistnić, mieściły w sobie przypadkowość i jednocześnie preferencje ku określonym możliwościom zaistnienia organizmów żywych ${ }^{24}$.

Pluralistyczną, ontologiczną koncepcję rzeczywistości przyjmuje wielu innych filozofów i naukowców. Koncepcję trzech światów, ale rozumianych odmiennie niż Popper, wypracował Roger Penrose w Cieniach umystu ${ }^{25}$. Wyróżnił trzy ontologiczne poziomy: świat fizyczny, świat naszych świadomych percepcji i platoński świat form matema-

${ }^{20}$ Karl Raimund Popper, Świat skłonności, przeł. Piotr Amsterdamski (Kraków: Znak, 1996), 11-37.

${ }_{21}$ Szersze omówienie rozumienia przyczynowości u Poppera przedstawiłem w: Krzysztof Śleziński, „Koncepcja przyczynowości u Karla R. Poppera”, Ruch Filozoficzny 63 (2006)1: 69-80.

${ }^{22}$ Karl Raimund Popper, Wszechświat otwarty. Argument na rzecz indeterminizmu, przeł. Adam Chmielewski (Kraków: Znak, 1996), 135-137.

23 Tamże, 137.

24 Tegoż, Świat skłonności, 37.

25 Roger Penrose, Cienie umystu. Poszukiwanie naukowej teorii świadomości, przeł. Piotr Amsterdamski (Poznań: Zysk i S-ka, 2006), 502-513. 
tycznych. Wyróżnienie tych światów wynika z przyjęcia trzech założeń. Pierwsze dotyczy możliwości opisania świata fizycznego za pomocą matematyki. Nie sprowadza się to jednak do zastosowania całej matematyki, lecz użycia jedynie wybranych struktur matematycznych do opisu świata fizycznego. Oznacza to, że tylko niewielka część platońskiego świata struktur matematycznych opisuje cały świat fizyczny. Założenie drugie sprowadza się do spostrzeżenia, iż obiekty mentalne nie istnieją niezależnie od świata fizycznego. $Z$ kolei trzecie założenie dotyczy dostępności wszystkich obiektów świata platońskiego dla naszego umysłu ${ }^{26}$.

George Ellis wyróżnia aż cztery odrębne poziomy bytów o istotnie różnych własnościach: świat energii i cząstek - świat nr 1, świat indywidualnej i zbiorowej świadomości - świat nr 2, świat zdarzeń możliwych - świat nr 3, platoński świat abstrakcyjnych relacji i struktur - świat nr 4 . W jego ontologicznej koncepcji rzeczywistości można wyróżnić także świat matematycznych relacji stanowiący fundamentalną strukturę świata fizycznego - metaświat $\mathrm{nr} 0^{27}$. Wyróżnione poziomy bytów wchodzą w określone interakcje, tworząc całość istniejącej rzeczywistości.

Z kolei Arthur Peacocke w naturalistycznym podejściu do tłumaczenia złożonych struktur życia organicznego wykorzystuje koncepcję emergencji jako ogólną cechę procesów występujących w przyrodzie. Wyróżnia cztery podstawowe poziomy rzeczywistości: fizyczny, biologiczny, behawioralny i kulturowy. Poziomy te, w jego koncepcji, są zawarte w Bogu, który nie tylko jest transcendentny względem nich, ale także w nich istnieje. Cała przyroda stanowi jego zdaniem obraz kreatywnego działania Boga w świecie. W procesach zachodzących zarówno w świecie, jak i ludzkiej świadomości Bóg działa i ujawnia się jako Stwórca. Człowiek jednak przez to, że ma wolną wolę, może wykraczać poza dostrzegany świat i kształtować go według własnej miary. Bóg dopuszcza jednak element „ryzyka”, subtelnie uczestnicząc w życiu każdego człowieka ${ }^{28}$.

Podobny sposób filozoficznego wyjaśniania przyrodniczych stadiów ewoluującej natury odnajdujemy u Józefa Życińskiego, zdaniem którego procesy emergentystyczne mogą być wyjaśnieniem zaistnienia w ludzkim życiu m.in. świata wartości, wolności i sensu ${ }^{29}$. Zdaniem Ży-

${ }^{26}$ Tegoż, Makroświat, mikroświat i ludzki umyst, przeł. Piotr Amsterdamski (Warszawa: Prószyński i S-ka, 1997), 102-103.

${ }^{27}$ Józef Życiński, Wszechświat emergentny. Bóg w ewolucji przyrody (Lublin: Wydawnictwo KUL, 2009), 21-24.

28 Arthur R. Peacocke, God and the New Biology (San Francisco: Harper \& Row, 1986), 96-98.

29 Życiński, Wszechświat emergentny, 29. 
cińskiego stwórcze działanie Boga nie wyklucza zmian zachodzących $\mathrm{w}$ przyrodzie. Ponadto wprowadzanie ewolucyjnej perspektywy do wyjaśniania rzeczywistości daje szansę wypracowania takiej ontologii kreacji, w której Wszechświat jest traktowany jako dzieło niedokończone, in statu fieri. Życiński zauważa jednak, że główną przeszkodą nierozumienia teorii ewolucji są podtrzymywane, zdroworozsądkowe interpretacje, $\mathrm{w}$ których ignoruje się istotne przemiany w naukowym obrazie świata i analityczne opracowania z zakresu dyskutowanej problematyki. W takich sytuacjach, przykładowo, kategorię przypadku wiąże się z nieoczekiwanymi wydarzeniami. Należy jednak wyjść poza banalne, zdroworozsądkowe antropomorfizmy, aby dostrzec możliwość łączenia procesów ewolucyjnych z działaniem Boga Stwórcy. Nie do utrzymania są wówczas koncepcje głoszące, że Bóg Stwórca doświadcza nieoczekiwanych zdarzeń na poziomie procesów fizycznych.

Przezwyciężanie konceptualnych trudności daje szansę odkrywania nowych poziomów analiz toczących się sporów, nierzadko światopoglądowych, i przedstawiania ich w nowej perspektywie badawczej. Podstawą tych zmian może być rozwijająca się problematyka przypadku, która obecnie nie stanowi kontrpropozycji ani dla przyrodniczej wizji przyrody podporządkowanej powszechnym prawom, ani też dla teologicznej koncepcji Boga ujawniającego swą obecność przez doświadczenie ładu i sensu. „Stwórca prowadzi dzieło stworzenia, wydobywając w kolejnych stadiach kosmicznej emergencji te potencjalności rozwoju, które sam określił"30. W takim rozumieniu powstawania etapów kosmicznej ewolucji dostrzegamy nierozerwalną więź łączącą przyczynę sprawczą z przyczyną celową.

Życiński stwierdza, że procesy opatrywane mianem przypadku nie eliminują funkcjonowania koniecznych praw, a biologiczna walka o byt nie obala doktryny o mądrości Stwórcy. Dla wzmocnienia tej argumentacji Życiński wypracował koncepcję pola racjonalności, szeroko pojmowanej racjonalnej struktury przyrody opisywanej w języku matematyki i podporządkowanej uniwersalnym prawom natury ${ }^{31}$. Podobny pogląd wyraża Michał Heller, powołując się na koncepcję tzw. pola formalnego, często określanego terminem "matematyka”, podkreślając tym samym znaczenie bogactwa struktur matematycznych wykraczających poza zakres znanych obecnie matematykom, a stanowiących fundament racjo-

30 Tamże, 55-56.

31 Tamże, 68-72 oraz Józef Życiński, „Filozoficzne aspekty matematyczności przyrody", w: Filozofować w kontekście nauki, red. Michał Heller, Józef Życiński, Alicja Michalik (Kraków: Znak, 1992), 23-42. 
nalności wszystkich procesów na poszczególnych poziomach rozwoju świata ${ }^{32}$.

Wskazując na przykładowe koncepcje pluralizmu ontologicznego oraz zmieniającego się obrazu rzeczywistości przyrodniczej pod wpływem rozwoju wybranych teorii naukowych, można dostrzec potrzebę opracowania filozoficznej teorii rzeczywistości. Zbudowanie takiej teorii nie jest łatwe, ale pozostaje ważnym naukowym wyzwaniem. O trudności tego zadania świadczy wiele zagadnień, które wcześniej powinny zostać rozstrzygnięte. Najogólniejsze zagadnienia sprowadzają się do udzielenia odpowiedzi na pytanie: czy filozoficzne opracowanie teorii rzeczywistości jest możliwe w ramach klasycznie pojętej filozofii przyrody, metafizyki roszczącej sobie pretensje do naukowości, metafilozofii czy syntezy nauk szczegółowych? W niniejszym artykule, nie podejmując się rozstrzygnięcia powyższych kwestii, zwrócono jedynie uwagę na pewien wycinek zmieniającej się perspektywy badań rzeczywistości, problematyki, którą można przyjąć za podstawę do filozoficznego opracowania rzeczywistości przyrodniczej.

\section{Bibliografia}

Andronov Aleksander Aleksandrovich, Eugenie Leontovich-Andronowa, I. I. Gordon, A. G. Maier. 1971. Theory of Bifurcations of Dynamic Systems on a Plane. Jerusalem: Israel Program for Scientific Translations.

Arnold Wladimir Igorevich. 1975. Równania różniczkowe zwyczajne. Warszawa: Państwowe Wydawnictwo Naukowe.

Barrow John D. 1995. Teorie wszystkiego. W poszukiwaniu ostatecznego wyjaśnienia, przeł. Jan Czerniawski, Tomasz Placek. Kraków: Znak.

Coveney Peter, Roger Highfield. 1997. Granice złożoności. Poszukiwania porzadku w chaotycznym świecie, przeł. Piotr Amsterdamski. Warszawa: Prószyński i S-ka.

Czernawski D. S., J. M. Romanowski, N. W. Stiepanowa. 1979. Modelowanie matematyczne w biofizyce, przeł. E. Skrzypek. Warszawa: PWN.

Davies Paul. 1996. Plan Stwórcy. Naukowe podstawy racjonalnej wizji świata, przeł. Marek Krośniak. Kraków: Znak.

Dyk Wiesław. 1996. „Termodynamiczne aspekty genezy życia”. Z Zagadnień Przyrodoznawstwa i Filozofii Przyrody 11: 156-163.

Greene Brian. 2002. Piękno Wszechświata. Superstruny, ukryte wymiary i poszukiwanie teorii ostatecznej, przeł. Ewa L. Łokas, Bogumił Bieniok. Warszawa: Prószyński i S-ka.

${ }^{32}$ Michał Heller, Mechanika kwantowa dla filozofów (Kraków: Wydawnictwo Biblos, 1996), 112; tegoż, Uchwycić przemijanie (Kraków: Znak, 1997), 237-238. 
Grobler Adam. 2006. Metodologia nauk. Kraków: Wydawnictwo Aureus Wydawnictwo Znak.

Heller Michał, Józef Życiński. 1996. Dylematy erwolucji. Tarnów: Wydawnictwo Biblos.

Heller Michał. 1993. Fizyka ruchu i czasoprzestrzeni. Warszawa: PWN.

Heller Michał. 1997. Mechanika kwantowa dla filozofów. Kraków: Wydawnictwo Biblos.

Heller Michał. 1997. Uchwycić przemijanie. Kraków: Znak.

Heller Michał. 2012. Filozofia przypadku. Kosmiczna fuga z preludium i coda. Kraków: Copernicus Center Press.

Linde Andrei Dmitriyevich. 1986. „Eternally Existing Self-Reproducing Chaotic Inflationary Universe". Physics Letters B 175 (4): 395-400.

Peacocke Arthur R. 1986. God and the New Biology. San Francisco: Harper \& Row.

Penrose Roger. 1997. Makroświat, mikroświat i ludzki umyst, przeł. Piotr Amsterdamski. Warszawa: Prószyński i S-ka.

Penrose Roger. 2006. Cienie umystu. Poszukiwanie naukowej teorii świadomości, przeł. Piotr Amsterdamski. Poznań: Zysk i S-ka.

Penrose Roger. 2011. Cykle czasu. Nowy niezwykły obraz Wszechświata, przeł. Bogumił Bieniok, Ewa L. Łokas. Warszawa: Prószyński i S-ka.

Poczobut Robert. 2006. „System - struktura - emergencja”. W: Struktura i emergencja, red. Michał Heller, Janusz Mączka, 11-38. Tarnów: Polska Akademia Umiejętności, Wydawnictwo Biblos.

Popper Karl Raimund, John Carew Eccles. 1977. The Self and Its Brain. New York: Springer International.

Popper Karl Raimund. 1996. Świat skłonności, przeł. Piotr Amsterdamski. Kraków: Znak.

Popper Karl Raimund. 1996. Wszechświat otwarty. Argument na rzecz indeterminizmu, przeł. Adam Chmielewski. Kraków: Znak.

Prigogine Ilya, Isabelle Stengers, 1990. Z chaosu ku porzadkowi. Nowy dialog człowieka z przyroda, przeł. Katarzyna Lipszyc. Warszawa: Państwowy Instytut Wydawniczy.

Reichenbach Hans. 1949. The Theory of Probability: An Inquiry into the Logical and Mathematical Foundations of the Calculus of Probability, przeł. Ernest H. Hutten, Maria Reichenbach. Berkeley, Los Angeles: University of California Press.

Smolin Lee. 2013. Time Reborn. From the Crisis in Physics to the Future of the Universe. Boston, New York: Hunghton Mifflin Harcourt.

Szlenk Wiesław. 1982. Wstęp do teorii gładkich układów dynamicznych. Warszawa: Państwowe Wydawnictwo Naukowe.

Śleziński Krzysztof. 2003. „Determinizm i indeterminizm w dyskusji metanaukowej połowy XX wieku". Bielsko-Żywieckie Studia Teologiczne 4: 301-310.

Śleziński Krzysztof. 2006. „Koncepcja przyczynowości u Karla R. Poppera”. Ruch Filozoficzny 63 (1): 69-80. 
Śleziński Krzysztof. 2012. „Prawdopodobieństwo w argumentacji filozoficznej". Bielsko-Żywieckie Studia Teologiczne 13: 249-260.

Weinberg Steven. 1994. Sen o teorii ostatecznej, przeł. Piotr Amsterdamski. Warszawa: Wydawnictwo Alkazar.

Życiński Józef. 1992. „Filozoficzne aspekty matematyczności przyrody”. W: Filozofować w kontekście nauki, red. Michał Heller, Józef Życiński, Alicja Michalik, 23-42. Kraków: Znak.

Życiński Józef. 2009. Wszechświat emergentny. Bóg w ewolucji przyrody. Lublin: Wydawnictwo KUL.

\section{Streszczenie}

Dzięki rozwojowi nauk przyrodniczych zdobywamy możliwość podjęcia dia$\operatorname{logu}$ z naturą. Współczesne teorie fizyczne i kosmologiczne modele wpływają jednak na zmianę klasycznych sposobów opisu wielu procesów we Wszechświecie. Dobrym tego przykładem są tradycyjne pojęcia przypadku i chaosu, które obecnie zatracają swój intuicyjny sens. Rozwój nowych kategorii pojęć, przedstawiających rolę przypadku w kształtowaniu nowych struktur natury, staje się kolejną szansą na przezwyciężenie wielu filozoficznych uproszczeń, w których przypadek jest traktowany w opozycji do przyczynowego wyjaśniania zjawisk. Treść niniejszego opracowania należy postrzegać jako próbę wskazania tych obszarów badawczych, w których nowe kategorie pojęciowe są rozwijane w ramach nowego obrazu rzeczywistości, który początkowo można nazwać obrazem bifurkacyjnym. Jest to jedynie próba poszukiwania właściwej definicji nowego obrazu natury, kształtowanego w znacznym stopniu przez rozwój współczesnych teorii naukowych.

Słowa kluczowe: filozofia przyrody, przyczynowość i chaos, początek Wszechświata i czasu, modele kosmologiczne, struktury dyssypatywne

\section{Summary}

\section{Philosophical Implications of the Changing Image of the Natural Reality}

Thanks to the development of natural sciences, we are able to engage in a dialogue with nature. Contemporary physical theories and cosmological models, however, change the classic ways of describing many processes in the Universe. A good example of this are the traditional concepts of chance and chaos, which are currently losing their intuitive sense. The development of new categories of concepts presenting the role of chance in shaping new structures of nature be- 
comes another chance to overcome many philosophical simplifications, in which case is treated in opposition to the causal explanation of phenomena.

Contents of this paper should be viewed as an attempt to indicate the enormity of research areas where the new conceptual categories are being developed within the new image of reality, which initially can be named "a bifurcative image". It is only the attempt to search for the correct definition for a new image of nature, which is shaped by the development of modern scientific theories to a considerable degree.

Keywords: philosophy of nature, causality and chaos, the beginning of the Universe and time, cosmological models, dissipative structure 